This item was submitted to Loughborough's Research Repository by the author.

Items in Figshare are protected by copyright, with all rights reserved, unless otherwise indicated.

\title{
Graduate employability: A critical oversight
}

PLEASE CITE THE PUBLISHED VERSION

http://dx.doi.org/10.1057/978-1-137-57168-7

PUBLISHER

Palgrave Macmillan UK

VERSION

SMUR (Submitted Manuscript Under Review)

PUBLISHER STATEMENT

Reproduced with permission of Palgrave Macmillan'

LICENCE

CC BY-NC-ND 4.0

\section{REPOSITORY RECORD}

Rothwell, Andrew, and Frances M. Rothwell. 2019. "Graduate Employability: A Critical Oversight”. figshare. https://hdl.handle.net/2134/24321. 


\section{Graduate Employability: A Critical Oversight}

\section{INTRODUCTION}

This chapter considers what is meant by employability, provides an over- 6 view of the main dimensions, and critically examines whether the attention 7 given to graduate employability in particular has delivered its potential 8 policy, educational, business and individual outcomes in the context of a 9 complex economic situation. The term is used widely and loosely, and has 10 been the focus of a rapidly expanding body of literature. Consequently, 11 we begin by offering some definitions of employability then clarify this in 12 four broad categories. Two of these are contextual: employment policy, 13 principally at national level; and the notion of employability as a human 14 resources management strategy. A further two are considered in much 15 more detail first, employability in the higher education (HE) context both 16

\section{A. Rothwell $(\bowtie)$}

AU1 School of Business and Economics, Loughborough University, Loughborough, Leicestershire, UK

F. Rothwell

College of Science and Arts, School of Education, Notthingham Trent University, Notthingham, Nottinghamshire, UK 
in terms of HE policy and the HE curriculum. As the last of the four categories we focus on the individual perspective: self-perceived employability, or how individual graduates can make an evaluation of their own career potential going forward. This is not the end of the story. While our work is somewhat Anglo-centric, and rooted in the post-industrial economies (Bell 1976), we also intend to demonstrate that these are increasingly global concerns. We suggest that employability has a 'smoke and mirrors' quality that has distracted attention from some fundamental issues in relation to graduate employment, including the offshore migration of graduate-level jobs, potential mis-selling of the extent of graduate-level opportunities (Scurry and Blenkinsop 2011), and as yet unknown threats to employment sustainability posed by predicted high levels of automation of many types of work (Oliver 2015).

\section{What Is Employability, Where Did It Come From? What Are the Main Dimensions Within the Broad SPECTRUM of the Employability Literature?}

Despite the development (in the last two decades) of a sizeable field of literature the validity of employability as a construct has been consistently challenged (Hillage and Pollard 1998; Garavan 1999). More recently Thijssen et al. (2008, p. 167) suggested it might be 'an attractive but confusing professional buzzword'. Thijssen et al. also suggested that sometimes the term has negative connotations, sometimes positive, often referring to individual characteristics, sometimes under-valuing the importance of the external labour market but generally referring to the notion of 'employment as an outcome' (p. 174). One of the most widely cited definitions is from Hillage and Pollard (1998, p. 12):

Employability is about the capability to move self-sufficiently within the labour market to realise potential through sustainable employment. For the individual, employability depends on the knowledge, skills and attitudes they possess, the way they use those assets and present them to employers and the context (eg. personal circumstances and labour market environment) within which they seek work.

Previously, we have suggested that employability might simply be the ability to keep the job you've got or to get the job you want (Rothwell and Arnold 2007). However in paid-for higher education in a recessionary 
context, employability may find itself with a contractual tone, as suggested by Oliver (2015, p. 56):

Employability features more prominently on the agenda of higher education institutions when the economy falters or changes: the majority of students, and their families, expect a degree to deliver a career pathway as well as an education.

We will discuss Hillage and Pollard's suggested link between employability 58 and skills below, as well as the impact of the context - work and careers, 59 especially for graduates, in the twenty-first century.

\section{A Brief Modern History of Careers, Work And (Un) 61 Employment: The Context of Employability 62}

Concerns about work and employment in the western industrialised world 63 resulting from economic, technological and social change are not new. 64 There has been significant turbulence in these labour markets since the 65 1970s, which accelerated following the recession of 2007-2008. In post- 66 industrial societies, downsizing and delayering, eradicated many of the 67 structures that supported long term careers. New flexible models of work 68 shifted the burden of risk to the individual (Ekinsmyth 1999). In the UK, 69 $84 \%$ of job losses between 2008 and 2009 were in manual, unskilled and 70 administrative positions (Wright et al. 2010). In the west, there has been 71 a decline in manufacturing: in all developed countries the proportion of 72 workers employed in manufacturing halved by 1990 (Watkins et al. 1992). 73 According to Manyika et al. (2011), manufacturing represented just $12 \quad 74$ per cent of United States GDP and 11\% of employment by 2011, with $5.7 \quad 75$ million jobs lost in the first decade of the twenty-first century, this being 76 a dramatic acceleration of an existing trend and reflecting (p. 28) "the 77 effects of automation, process redesign and off-shoring", all factors which 78 $\begin{array}{ll}\text { we suggest will also increasingly affect graduate level work. } & 79\end{array}$

In the second decade of the twenty-first century, getting or keeping 80 work has remained a challenge for many individuals. Torres (2012)suggested a 50 -million jobs deficit worldwide, noting that $(2012$, p. vii), 82 "employment has become more unstable or precarious. In advanced econo- 83 mies, involuntary part time employment and temporary employment have 84 increased in two thirds and more than half of those economies, respectively." 85 Hence, the rationale for continuing interest in employability is clear, but 86 
there are also hints of structural issues and deeply concerning international issues which we will return to later. Having established the context for employability, the following sections discuss how these changes to work and employment were reflected in employability related public policy and organisational human resource management (HRM) strategies. This is followed by a more detailed consideration of employability in a Higher Education context.

\section{Employability in Public Policy, the Skills Debate}

In the UK, government policy from the late 1970s marked a move away from a commitment to full employment. As Orton (2011, p. 353) noted, "-government no longer saw itself as responsible for job creation or protection, and what policy development there was focused overwhelmingly on the supply side”. Similarly Chertkovskaya et al. (2013, p. 701) suggested that:

- individuals' capacity to - constantly work on their employability, has come to be understood as the crux of national, organizational and individual prosperity.

This neo-liberal approach marked a shift in responsibility towards the individual, mirrored (in academic literature) by notions such the protean career (Hall 1976) as being under the proactive control of the person seeking to sustain or acquire work. By the mid-late 1990s concerns about the impact of rising unemployment in Western economies led to research supported by government departments (eg. Hillage and Pollard 1998), the European Union (eg. Berkeley 1995) or internationally (e.g. OECD 1996, 1998; UN 2001), promoting the notion that unemployment could be 'durably reduced' (OECD 1995, p. 12). Researchers often emphasised the role of government as 'enablers' (Cherkovskya et al. 2013, p. 703) in stimulating the development of skills in the working population (who should now take the initiative to upgrade their skills) appropriate to perceived employer needs (NCIHE 1997, UK Commission for Employment and Skills 2009). This perception also influenced 1990s public policy (e.g. in the UK) with a focus on higher education expansion, which also happened to reduce youth unemployment especially when linked to widening participation - encouraging working class youth into Higher Education, with a promise of a rewarding career and social mobility. Specific 'graduate skills' were listed comprehensively in nine areas by Lowden et al. 
(2011, p. 6), including such (simplistic?) categories as a 'positive approach' and 'using numbers accurately'. Yet even such simple skill-sets may themselves be unstable. The 'World Economic Forum' (2016, p. 3) noted that skill requirements for jobs were changing, "shortening the shelf-life of employees' existing skill-sets', and noted the need for 'technical skills to be supplemented by strong social and collaboration skills".

The recognition of potential shortcomings in a new proactive approach to work and skills are far from new. Hillage and Pollard (1998) noted the lack of 'employability qualities' in school leavers. Similarly the OECD (1997) observed that initial education and training no longer guaranteed what they optimistically called lifelong employability. The actual creation of jobs is often overlooked: Brown (2005), in a review of UK public policy attributed (p. 13) the 'failure of economically inactive people' to find jobs to 'poor employability' and discrimination against them: the absence of suitable jobs for them to apply for was not mentioned. McQuaid and Lindsay (2005) however offered a critical perspective on 'supply side' employability policies (i.e. policies which aimed to enhance individuals' employability skills) in that these shifted the onus of 'blame' onto the individual and their: " - inadequacies, rather than acknowledging a lack of opportunity within the labour market" (p. 204).

Within the UK literature in particular, the notion of employability in public policy became inextricably attached to that of skills development. Wright, Brinkley and Clayton also (p. 10) noted that as long ago as 1970 around twenty cent of the UK workforce were 'knowledge workers': this doubled by 2010 , as knowledge-intensive industries increased by around $90 \%$ to almost half of all employment in the UK. A reasonably contemporary view of the UK employment scene was offered by Birdwell et al. (2011, p. 18):

Five trends shape the current labour market - the dwindled but relatively 150 stable supply of lower-skilled jobs, the diminished number of semi-skilled 151 manufacturing jobs, the continuing rise in service sector jobs, the growing 152 need for jobs at a 'technician level', the rise in the number of jobs at profes- 153 sional and managerial level. $\quad 154$

Wright et al. (2010, p. 3) suggested that "skills shortages, skills gaps and 155 skills under-utilisation are cited as the main problems facing the system". 156 They expressed frustration with the 'glacial speed' of the system (page 35) 157 and concluded (page 6): 
The debate about employability and skills has been long standing - after many years there has been no revolution and we are still discussing a lack of 'employability skills', with education providers remaining focused on qualifications targets rather than preparation for the workforce.

The report went on (page 7) to suggest that "skills-hungry knowledge intensive sectors (are) critical to the future growth of the UK", suggesting that there would continue to be strong demand for individuals with higher skills and qualifications due to the advance of the knowledge-based economy (KBE: OECD 1996). This derived from a common perspective at the end of the twentieth century that due to demographic change and the rise of the KBE there would be a limited pool of talent with the potential to fill higher level positions, thus creating a 'war for talent' (a term first used by McKinsey consultants: see Michaels et al. 1997). At the same time the increasing sophistication of work would create a need for additional skill requirements, thus creating jobs to be filled by graduates, a notion known as job-upgrading (CIPD 2015b) or up-skilling (Felstead 2013). In fact, Felstead acknowledged that the up-skilling process was weakening by 2012 , while the supply of graduates continued to grow, but clearly stated his perspective that: "the economy's prosperity is based on the skills of its jobs" (p. 17).

More recent perspectives have challenged the notion of up-grading or up-skilling . First, automation may have the opposite effect of de-skilling work by replacing discretionary decision-making with intelligent systems, 'making knowledge work more routine'. Second a diminishing demand for labour may mean that more skilled and qualified candidates (graduates) displace the less favoured, even where the graduates may be underemployed (CIPD 2015b). The same source described this phenomenon of graduate employment in what were formerly non graduate jobs as 'occupational filtering down' (page 28), a nicely euphemistic term for what could also be called de-professionalisation. Espinoza (2015) noted that one-third of UK graduates from the previous year were in roles that did not require a degree. Goldwyn-Simkins (2015) in the UK's 'What do Graduates Do' publication, noted that although the number of graduates in what was called 'professional-level employment' had risen, this was still only $68 \%$. At the same time the CIPD's Labour Market Outlook for the fourth quarter of 2015 noted that $49 \%$ of employers had hiring difficulties, especially for engineering and managerial roles (CIPD 2015a), suggesting a mismatch between supply and demand in the labour market. 
It has been suggested that the focus on skills as a "social and economic panacea" (Keep 2010 , p. 565) has diverted attention away from considering other practical policies and strategies. Challenges to contemporary policy approaches, included Orton $(2012$, p. 357) who suggested that: “ - employability without employment does not make sense in a capabilities perspective'. Orton suggested that the real issue was to raise the number of jobs available and a need for alternative policies to the neo-liberal orthodoxy. Chertkovskaya (2013) suggested that:

What actually appears to have happened in post-industrial societies in the last decade (accelerating in the last five years) is further cost-based job migration but not just of routine-level jobs. The outsourcing of professional work and the rapid rise of professional shared service centres, many of which are outside the UK, has seen higher-level work migrate overseas as well (Rothwell et al. 2011; Herbert and Seal 2014), satisfying demand for professional service work by a rapidly growing, technically literate and educated population in the developing world. Thus there may continue to be strong demand for individuals such as graduates with higher skills and qualifications due to the global advance of the knowledge based economy, but it won't necessarily be in the post-industrial nations. We suggest that by committing to a $\mathrm{KBE}$ based on 'graduate work' and professional services, the post-industrial nations have missed the point: skills deficits may persist, and worsen, but in technical skills (which aren't being delivered by many education systems, notably the UK) to a greater extent than skills for professional services. There will be no net increase in high level domestic jobs, they will simply migrate overseas, encouraged by surpluses of graduate labour in lower-cost economies such as India and China (Sharma 2014).

As concluding comments, employability as policy has fallen victim to a series of oversights, and one cannot escape the feeling that either little has been achieved or that the debate has not sufficiently evolved. Our principal challenge, which we will return to later, is that an 'upskilled' economic future premised on the KBE may be at best unsustainable and at worst a myth. The next section briefly considers employability as a strategy within Human Resource Management, after which we focus our attention on Higher Education. 


\section{Employability as a Human Resource Management STRATEGY}

Employability also exists as a concept within the managerial toolkit. Changing labour market conditions throughout the western world in the 1990s signalled the end of employment security (Doherty 1996). Employability emerged as a possible way forward (Garavan 1999). Pascale $(1995$, p. 21$)$ noted a somewhat idealistic view:

Employability has been advanced as the mechanism to restore a healthier quid pro quo - In exchange for the employees' dedicated efforts in a shorterterm employment relationship, the company pays higher wages and invests in the employees' development. This makes them more marketable when it is time to move on.

Tamkin and Hillage (1999) emphasised what employers could potentially do to enhance the employability of their workforce suggesting that if they could not offer a job-for-life (still a cherished notion in the 1990s!) then it would be good practice to give employees the ability to get other work should this be necessary including an emphasis on learning and development, coaching, mentoring and developing key contacts. Similarly Thijssen et al $(2008$, p. 169) suggested a focus in the 1990s on 'companies offering facilities to improve the responsibility and initiative of employees', linking this to the notion of the boundaryless career. Baruch (2001, p. 553) was blunt in his conclusions:

employability' as a managerial concept is flawed. In the short term people will not believe in it; in the long term it will damage the company.

His assessment was based on research with HR managers whose views included the idea that promoting employability would de-stabilise the company, that they wanted people to develop "skills for us, not for others" (p. 560), and the notion of promoting employability as a benefit "would be completely illogical". Despite these potentially negative perceptions, there are some contemporary examples which illustrate the persistence of the HRM perspective. Nauta et al. $(2009$, p. 233) examined the 'push and pull' motives related to the turnover intent of Dutch health care workers and concluded that an 'employability culture' would help organisations adapt to change while 'simultaneously decreasing turnover intentions'. 
Finally, as a philanthropic perspective, Dobbs et al. (2012) cited (p. 67) the beverage company Diageo which set up a UK charity to help long term unemployed people find jobs, education or training.

An overall evaluation is of a complex picture relating to employability within HRM, worthy of further research. For graduates, the implications are that while they may expect development in their 'first destination' appointments, employers may be reticent to provide this unless some trade-off can be made such as training (essentially lock-in) agreements. As a counter-view, the World Economic Forum suggested that the expectation on the part of employers that they be "consumers of ready-made human capital" (WEF 2016, p. 7) was unrealistic, and that they should put talent development "front and centre to their growth".

\section{Graduate Employability and the Higher Education}

From the 1980s onwards a focus emerged on employability within the 282 Higher Education (HE) context including the promotion of initiatives to develop employability such as internships and work experience. In this section of the chapter we commence with some observations on graduate employment (not just in the UK), followed by some sector-level developments such as those promoted by the Higher Education Academy. We will then consider selected examples of specific curriculum initiatives, and a selection of employability measures or psychometric tools that are relevant to graduates. We consider the relationship between employability initiatives and subsequent employment outcomes, concluding with some challenges to the phenomenon of graduate employability. Is it a potential solution to a global jobs crisis, or worse, as Cherkovskaya, Watt, Tramer and Spoelstra suggested (2013, p. 707): 'a promise empty of any substantive meaning - that empties all it touches'.

Some of the earliest references to employability could be found in an educational context (Robbins 1963). The term was to re-emerge in the 1980s in the context of concerns about rising graduate unemployment in the UK (Haigh and Gibbs 1981) and graduate suitability for employment (NCIHE 1997) at the same time as 'massification' of the higher education sector. Wright et al. $(2010$, p. 11$)$ noted that $36 \%$ of the employed UK workforce had a degree or equivalent in 2010, and that the Labour party had aimed to get $50 \%$ of young people to enter higher education 
(or equivalent) and 75\% to enter post-secondary education (Leitch Review of Skills 2006).

In the UK context graduate salaries, employment rates and expectations are variable and the outlook for graduates has been mixed for some time. Scurry and Blenkinsop (2011) explored the notion of graduate under-employment, and emphasised the importance of managing expectations. Unemployment or under-employment may well be due to qualitative and quantitative mismatches: in the former case subject knowledge (not just skills) that do not match labour market requirements (Woodman and Hutchings 2011), and in the latter case simply too many graduates. A report entitled 'Over-qualification and skills mismatch in the graduate labour market' (CIPD 2015b) noted the increasing proportions of graduates in professional and 'associate professional' (p. 3) occupations between 1991 and 2014, but also (p. 4) that the UK has witnessed one of the highest rates of Higher Education expansion across Europe in recent decades', with (p. 15) $58.8 \%$ of graduates in non-graduate jobs, one of the highest proportions in Europe. The CIPD acknowledged a generally higher level of skill requirements in the workforce, and that some degree courses were delivering training once the preserve of vocational education. They suggested that in some cases jobs have upgraded "as graduates moved into them in increasing numbers" (p. 5) whereas in other cases graduates have simply replaced non-graduates in less demanding jobs. They $(2015$, p. 11) cited the notion of 'Digital Taylorism' as graduate level jobs were subjected to increasing automation, including of decision-making processes. A contrasting view (at first impression) was presented by GoldwynSimpkins (2015) whose findings suggested that the UK graduate labour market had recovered from the recession (2014-2015 cohort, surveyed six months after graduation), with mean salaries of $£ 20,637$ and $68 \%$ of graduates in graduate-level jobs. Notwithstanding the mismatch in information, this presents a challenging contemporary picture overall for UK graduates.

The UK HE sector responded to challenges described by investing significantly in employability initiatives. The greatest body of work was developed by the UK's Higher Education Academy (HEA), specifically their 'Subject Centres' and 'Centres of Excellence in Teaching and Learning' (CETLs) and there are numerous examples of good practice across a very broad spectrum of subject areas. The CETL activity was summarised by Butcher et al. (2011) and claimed impact at a number of levels including embedding employability in institutional strategy, promoting innovation 
in teaching and learning, enterprise education, research to inform practice and employer engagement. In that account employability appeared to have subsumed a number of other activities including work-based learning (p. 9) and entrepreneurship. A comprehensive perspective on employability for university students was offered by Redmond (2010) who suggested that University reputation could impact on an individual's future employability ( a view not widely acknowledged in the UK academic community), and that employability could be represented by the formula: $\mathrm{E}=\mathrm{Q}+\mathrm{WE}+$ $\mathrm{S} \times \mathrm{C}$. This being, Employability = Qualifications + Work Experience + Strategies x Contacts. The inclusion of 'contacts' is interesting: could it be that despite widening participation initiatives, individuals from more affluent backgrounds are more likely to attend highly ranked universities and to have the contacts to acquire entry level positions or internships? Illustrative of works that focus on key employability-creating factors, Lowden et al. (2011) found that their research (p. vii) 'overwhelmingly highlighted' the importance of work experience to promote the employability of graduates.

Holmes (2015) focused on the formation of 'graduate identity' through analysis of personal narratives of individuals who had engaged with graduate selection processes. Their success or otherwise either confirmed or refuted their sense of 'worthiness' to be considered suitable for what they perceived as a graduate level role, and indeed the value of being a graduate in the first place. In the context of widespread concerns about graduate under-employment, Holmes presented some important issues: is higher education over-selling the promise of graduate employment, and if this is not achieved is the consequence psychologically damaging for individuals?

There are numerous publications which directly describe employability initiatives in various Universities. Many are claimed to be successful, and undoubtedly rest on exceptional efforts by dedicated individuals, but there are relatively few longitudinal studies that actually capture the impact of employability initiatives. We present a small selection here, identified as much for their differences as their similarities. For example, Dacre Pool and Sewell (2007) described the 'CareerEDGE' model as including curriculum components to develop employability, including (page 49) career development learning, experience, the degree subject, skills and emotional intelligence; they also emphasised the value of opportunities to develop work experience. They concluded (p. 287) that 'self-esteem is a major part of the key to employability'. A later publication (Dacre Pool and Qualter 2013 ) introduced an element of longitudinal study in that it examined the 
perceptions of 'working graduates' (alumni) to retrospectively consider the impact of a range of variables within self-perceived employability, including career satisfaction and including emotional self-efficacy (an alternative label for trait-emotional intelligence: p. 215). The latter was found to be important for both employability and career satisfaction, supporting an argument for EI to have more curriculum emphasis. Smith et al. (2014) reported a substantial study undertaken in Australia with more than 3000 responses in one of the five separate phases, including over 1400 responses in what was described as a 'proxy longitudinal study' (p. 21). This very diverse (in terms of subject) study focused on employability and especially work-experience provision within the curriculum. It had a longitudinal aspect in the sense that the phases included students at different stages of their degree programme, individuals close to completion of a 'work placement', and a qualitative phase with alumni who had benefitted from 'work-integrated learning' (p. 22). The first phase examined employability related curriculum initiatives: recommendations included the fundamental importance of work experience in shaping employability in the long run.

Maxwell et al. (2015) described the 'Employability Plus' initiative at Northampton University based to a large extent on voluntary community action and 'social learning', which blended curricular and extracurricular activity and included reflective aspects as well as 1:1 meetings between advisors and students, as part of a wider strategy of curriculum innovation and employer engagement. Despite a claimed $97 \%$ employability rate among the University's graduates, only $65 \%$ of these were acknowledged to be in graduate level jobs. Ball (2015, p. 4) noted that 'graduate level' meant (in terms of UK statistical returns and definitions as reported in 'What do Graduates Do?', jobs falling under the 'professional' banner. Even this can be problematic: Ball cited 'shop-keeping' as being considered 'professional', when finance and veterinary work were not, necessarily.

What has become noticeable in the last two to three years has been the level of interest in graduate employability worldwide, generally driven by Higher Education expansion and a corresponding concern about graduate unemployment or underemployment. Across Europe, the CIPD (2015a) noted that high-skilled jobs had generally tended to increase more slowly than the number of high-skilled workers available with some countries, notably Greece, reporting particular problems. Further afield Sharma (2015) reported that $30 \%$ of this year's graduating cohort $(2.3$ million individuals) in China could be unemployed, with graduates more willing to take non-graduate jobs. In India, according to the Indian 
Ministry of Labour and Employment (Labour Bureau 2014, p. 7): "In the case of graduates and post graduates the unemployment rate is about 14 per cent and 12 per cent respectively." Sharma reported high levels of alienation and discontent in both India and China among the large numbers of educated young people unable to join the middle class. Two key differences here are the rapidly increasing population of India, with slower growth in China as a legacy of the now- relaxed 'onechild' policy. Rufai et al. (2015) described a model of graduate employability in the context of Malaysia, also experiencing rapid population (and graduate) increases which may (p. 43): "out-pace the generation of employment opportunities". There is evidence of significant interest in graduate employability in Australia, with government-led initiatives to identify and promote best practice (see eg. Jackson 2013; Kinash et al., 2014) with the former paper noting (p. 2) "persistent gaps in certain non-technical skills in business graduates". 19 such skills were identified and more than 45 behaviours.

Readers familiar with the UK's Higher Education Academy's work on employability may well be surprised at the brevity of this section. Our aim is not so much to present a comprehensive view of employability good practice, as to offer a balanced consideration including some limitations: in this vein some shortcomings of the HEA's output have been observed. Pegg et al. (2012) presented an update of the numerous earlier HEA publications on 'pedagogy for employability' which aimed to develop (p 45) "the creative, confident, articulate graduate" They concluded that this would be based on action in respect of learning, teaching and assessment to develop employability, work experience or simulated work-based learning, and an institutional commitment to employability. They noted the development of an explicit connection between study and the workplace, including student and employer expectations, but at the same time a "lack of evaluation of initiatives and approaches to teaching and learning AU8 employability skills" (46). A further view was offered by Waltz (2011) who suggested that in attempting to force a fit of individual values with organisational values in the name of employability, individuals may experience cognitive dissonance due to the need to subordinate their own values to that of the organisation.

A report summarising the proceedings of a teaching and learning summit (Tibby 2012), also documented some of the key issues and was relatively frank about the challenges of employability, noting among others (p. 3):

421 
(a) lack of clarity as regards the concept of employability - lack of student engagement with employability - training and resource issues for staff involved in delivering employability support - the challenge of assessing the impact of employability provision.

A further observation could be that employability approaches take an overly simplistic consideration of the development and manifestation of graduates' skills. According to James et al. (2013) skill acquisition may not just be in higher education, but prior to it and even parallel to it, some of the best examples including volunteering or extra-curricular activity (Rothwell and Charleston 2013). Similarly, Williams (2012) expressed a concern that teaching employability skills was actually a distraction for subjectspecialist academics, in a context where students saw university as the only option (due to a lack of jobs) rather than a positive choice. Wilton (2011) introduced a note of concern in his observation that despite employability initiatives, graduates were still likely to encounter barriers attributable to 'traditional labour-market disadvantage', such as social class. There is nonetheless a perception that many publications on employability related to UK higher education in particular tend to be repetitive, descriptive and uncritical (Pegg et al. 2012).

We suggest that despite the immense amount of energy and effort that has been expended on university level employability, this may actually disguise some issues of concern. First, universities in the UK (and elsewhere) expanded dramatically in the early part of the twenty-first century but not always in the shortage 'STEM' subjects required for sustainable economies. Second, in some cases graduates apparently still lack many of the basic skills employers require (Lowden et al. 2011). Third, universities have been complicit, globally, in promoting the notion of 'graduate employment' in mass Higher Education when the prospect of attaining success from a not inconsiderable investment is not always a realistic aspiration. Fourth, the increasing global concern about graduate employability suggests a bigger over-supply problem, exacerbated by a global jobs shortfall.

\section{The Individual Focus: Employability Measures}

\section{and SELF-Perceived Employability}

In the three approaches to employability discussed so far, employability has been viewed in a detached way: as applied to individuals or groups within society as a whole, within the education system, or an organisation's 
workforce. A fourth perspective on employability examines the individuals' understanding of their own situation and opportunities. It mainly evolved from the 1990s literature on changing careers and the 'new psychological contract', echoing earlier notions of less government intervention and more employee pro-activity. Broadly, within the literature self-perceived employability (SPE) appears to have internal and external aspects. The internal dimension includes the individuals' self-efficacy (Bandura, 1997), knowledge and skills (Engelberg and Limbach-Reich 2011), mastery of career management and job search (Hillage and Pollard 1998), individual attributes such as age which was also linked to promotions (Van der Heijden, Lange, Demerouti, Van der Heijde 2009), and internal job-promotion opportunities (Rothwell and Arnold 2007). Van Emmerik et al. (2012) also noted the importance of aspects inherent within the job such as autonomy, variety and feedback, mediated by individual motivation. The external dimension includes the general state of the labour market and the demand for one's occupation at a particular point in time (Hillage and Pollard 1998, Rothwell and Arnold 2007). Positive perceptions of one's employability may be advantageous: Berntson and Marklund (2007) found through longitudinal study that it predicted mental well-being and general health due to a perceived ability to escape work situations seen as unfavourable.

Self-perceptions of employability (SPE) apply to individuals in the context of transitions between education and work. Rothwell et al. (2008) examined SPE for business students in low-ranked, middle-ranked and high-ranked universities based on a four-component model comprising the individual, their course of study, the status of their institution and the general state of the labour market. They found, perhaps counter-intuitively, that respondents from the highest ranked university actually had the lowest employability expectations. This was initially attributed to these individuals having a greater reality-sense and awareness of the real challenges in the labour market. Their views contrasted with those of students in the sample from post 1992 Universities, who were found to be from a 'widening participation' background, with lower grades on entry and the first in their families to engage with higher education. The students from the high-ranked institutions also reported greater selectivity in the jobs they were willing to apply for. Their uncompromising 'red-brick, blue chip' approach indicated that they were less easily satisfied than their peers. Rothwell et al. (2009) replicated the above study with international post-graduate students. In each of the latter studies actual scale items used were appended to the papers, with factor analyses and details of scale construction. 
Picking up on the international note above Potgeiter and Coetzee (2013) analysed the attributes of their 'employability attributes scale', which they used in conjunction with the Myers-Briggs Type indicator $\left(\mathrm{MBTI}^{\mathrm{TM}}\right)$ in their South African study. This was based on a model which accounted for (p. 3) personal agency, career success and sustained employability, as well as the employment context. Individual factors included career self-management, cultural competence, self-efficacy, career resilience, sociability, proactivity, emotional literacy and entrepreneurial orientation. This paper also looked at postgraduate employability - arguably an under-researched area. Nwogu and Momoh (2015), also utilised the MBTI alongside their (p. 245) "graduate employability qualities and personality preferences" scale, noting (p. 242): “-increased concerns about the employability of young adults in the Nigerian context". While these are by no means the only international examples, they do illustrate the increasing global concern around graduate employability. As with other categories, research on SPE presents a mixed picture with some potentially contradictory results. Despite a growing body of literature the actual impact of the above research has been modest, and has yet (for example) to inform significant practical tools that could be used in an employment context, such as career counselling.

\section{Employability: Potentially Helpful, But Not the Answer?}

We have suggested that there has been extensive attention paid to employability, but not enough to employment. Our arguments here have a special resonance for graduate employment. Despite predictions that there will be increased demand for 'highly skilled talent' in advanced economies (e.g. Dobbs et al. 2012), this demand may be moderated by continuing job migration. Dobbs et al. also noted (page 43) that as China moves towards 'wealthy nation status', it will create up to 64 million more knowledge-intensive jobs in the service sector, including in 'education, finance and business services'. The work for these jobs was not likely to be entirely home-grown. Subsequent commentators (e.g. Sharma 2014) have noted high levels of graduate unemployment in China attributable to over-supply hence meeting the demand for such work is not likely to be an issue. Nor have governments given adequate protection to employment. Kochan (2012 p. 3) noted that a U.S. corporation might close a plant and send the jobs overseas to be undertaken at lower labour costs, but society "picks up the tab for their lack of investment in human capital: slow economic 
growth, unemployment, welfare, and so on". Looking further afield, we have suggested that increasing levels of global education, including graduate education, may simply create more pain and more unmet expectations of employability, described by Valenzuala $(2013$, p. 863 ) as: "mortifying guilt arising from a lack of knowing how to realise it".

Few of the analyses discussed so far have even mentioned the potential consequences of widespread automation. Indeed, this appears to be an 'elephant in the room' so far as economic and employment policy is concerned, despite increasing attention to the subject (Frey and Osborne 2013; Manyika et al. 2015). In Australia, Oliver (2015, p. 57) suggested that five million jobs (there) could be replaced in the next decade.

How did we get to where we are today in a business and policy sense? Torres (2012) noted (page $\mathrm{x}$ ) the "imbalance between the voice of the real economy and that of the financial sector" (or 'financialisation', Palley 2007); Huffington (2010) a political system in the USA (but it could be applied elsewhere) in thrall to a small financial elite. Similarly Kochan (2012, p. 9) described the importance of rebalancing "shareholder and stakeholder considerations"; while Featherby (2012) argued for: "megabusinesses, those business that control the way we live, to be given a civic responsibility as well as a private purpose". Although not specifically mentioned, this responsibility could include for example not being so ready to ship jobs overseas in search of lower labour costs, and business having a sense of community responsibility. Finally, despite the emergence of a considerable body of academic and practitioner knowledge on employability and a sophisticated understanding of the labour market, we suggest that academics may also be culpable in that they have not fulfilled an intellectual and moral leadership role to guide policy makers and entrepreneurs in respect of sustainability and responsible stewardship.

\section{Conclusions}

In the present century many of the former world-leading economies of the twentieth century have been scarred by unemployment, welfare dependency, the desolation of communities, the displacement of people and the creation of 'lost generations', including many graduates, for whom sustainable employment remains a distant aspiration. Globally, such phenomena have the potential to lead to unfulfilled potential, demotivated and disenfranchised youth, an epidemic of drug dependency and mental health issues, an increasingly fragile balance between the haves and have-nots 
609

610

611

612

613

614

615

616

617

618

619

620

621

622

623

624

625

626

627

628

629

630

631

632

633

634

635

636

637

638

639

640

both within and between nation states and an increasing risk of political and social unrest. Even the most relentless optimist would agree that the structural changes (in the west) that lie behind these challenges will be extremely difficult to undo, while in emerging economies it is difficult to argue against rising numbers of graduates having aspirations to match.

Clearly having some understanding of what contributes to graduate employability is important at an individual, institutional and international level. However, the (now) vast body of literature on employability generally under-estimates the importance of the employment context where there are major concerns. First, developing nations have every right to rising educational attainment levels, and the western nations have no more ownership rights than anyone else to graduate jobs and employment. These, if left to market forces, aided by the emergence of sophisticated global logistics and a levelling technological playing field in terms of most business processes, will tend to follow lower labour costs. Hence our overall conclusion is that a focus on employability misses a key point which is the creation, acquisition and retention of good quality, sustainable jobs globally. Initial concerns about the validity of employability as a construct are best described as 'valid in part'. From a critical distance, employability does indeed appear to be a well-intentioned construct that is applied to a range of related topic areas. In respect of education and especially Higher Education, a not insignificant body of knowledge has emerged which aims to support student transitions to the workplace. There are still areas for potential research. There are still relatively few longitudinal studies that assess the impact of employability initiatives on graduate employment. There is considerable potential for international replication of existing studies especially in emerging economies. A further aim might be to provide an evidence base to underpin public policy and in turn to promote sustainable employment. While this potential has yet to be realised and is now the employability challenge for the twenty-first century, we suggest that global graduate employment itself will now present far greater challenges, and should be a focus for long overdue attention.

\section{REFERENCES}

Bandura, A. (1997). Self efficacy: The exercise of control. New York: W. H. Freeman. Baruch, Y. (2001). Employability: A substitute for loyalty. Human Resource Development International, 4(4), 543-566.

Bell, D. (1976). The coming of post-industrial society: Venture in social forecasting. New York: Basic Books. 
Berkeley, J. (1995). In pursuit of lifelong employability: priorities for initial formation. European Journal of Vocational Training, 5, 53-60.

Bernstein A. (2000, September 11). Too much corporate power. Business Week, p. 149.

Berntson, E., \& Marklund, S. (2007). The relationship between perceived employability and subsequent health. Work and Stress, 21(3), 279-292.

Birdwell, J., Grist, M., \& Margo, J. (2011). The forgotten half. London: DEMOS.

Brown, D. (2005). Public policy perspectives, the public policy agenda. Wimbledon: Chartered Institute of Personnel and Development.

Brown, P., \& Hesketh, A. (2004). The mismanagement of talent, employability and jobs in the knowledge economy. New York: New York Oxford University Press.

Butcher V., Smith J., Kettle J., \& Burton L. (2011). Review of good practice in employability and enterprise development by centres of excellence in teaching and learning: summary report. A report for HEFCE by the HEA, York, Higher Education Academy.

CEDEFOP. (2009). Future skill supply in Europe, medium-term forecast up to 2020: Synthesis report. Luxembourg: Office for Official Publications of the European Communities.

Chertkovskaya, E., Watt, P., Tramer, S., \& Spoelstra, S. (2013). Giving notice to employability. Ephemera, 13(4), 701-716.

CIPD. (2015a). Labour market outlook Autumn 2015. Wimbledon: Chartered Institute of Personnel and Development.

CIPD. (2015b). Over-qualification and skills mismatch in the graduate labour market. Wimbledon: Chartered Institute of Personnel and Development.

Committee on Higher Education. (1963, September 23). Higher education: 671 Report of the committee appointed by the Prime Minister under the chairmanship 672 of Lord Robbins 1961-63, Cmnd. 2154, London: HMSO.

Crompton, R. (2010). Class and employment. Employment and Society, 24(1), 9-26.

Dacre, P. L., \& Qualter, P. (2013). Emotional self-efficacy, graduate employability, and career satisfaction: Testing the associations. Australian Journal of Psychology, $65,214-273$.

Dacre, P. L., \& Sewell, P. (2007). The key to employability, developing a practical model of graduate employability. Education + Training, 49(4), 277-289.

Davis, A., Kimball, W., \& Gould, E. (2015). EPI Briefing paper \#401, The class of 2015 (Despite an improving economy, young grads still face an uphill climb), 27 May 2015. Washington: Employment Policy Institute http://www.epi.org/ publication/the-class-of-2015/.

Dobbs, R., Madgakker, A., Barton, D., Labaye, E., Manyika, J., Roxburgh, C., et al. (2012). The world at work: Jobs, pay and skills for 3.5 billion people. Washington: McKinsey Global Institute.

Doherty, N. (1996). Surviving in an era of insecurity. European Journal of Work 688 and Organizational Psychology, 5(4), 471-478. 
690

691

692

693

694

695

696

697

698

699

700

701

702

703

704

705

706

707

708

709

710

711

712

713

714

715

716

717

718

719

720

721

722

723

724

725

726

727

728

729

730

731

Ekinsmyth, C. (1999). Professionals in a risk society. Transactions of the Institute of British Geographers, 24, 355-366.

Engelberg, E., \& Limbach-Reich, A. (2011). After the Bologna reform, employability of bachelors in social and educational work in Luxembourg. Social Work Education, 30(1), 1-12.

Espinoza J. (2015). Thousands of new graduates out of work, figures show. Telegraph (online). http://www.telegraph.co.uk/education/educationnews/11699095/ Thousands-of-new-graduates-out-of-work-figures-show.html

Featherby J. (2012), Of markets and men, tomorrow's company, London: The Centre for Contemporary Christianity and the Institute of Chartered Accountants in England and Wales. http://tomorrowscompany.com/of-markets-and-menby-james-featherby. Accessed 7 Nov 2012.

Felstead, A. (2013). Skills at work. Society Now, Summer Issue, 16, 16-17.

Frey C. B., \& Osborne M. A. (2013). The future of employment: How susceptible are jobs to computerisation? (Working paper). Oxford Martin School of Business, Oxford. http://www.oxfordmartin.ox.ac.uk/publications/view/1314

Garavan, T. N. (1999). Employability, the emerging new deal. Journal of European Industrial Training, 23(1), 1-5.

Grist, M., Birdwell, J., Gregory, T., \& Ousbey, J. (2011). Youth labour's lost. London: Demos.

Haigh M., \& Gibbs G. (Eds.). (1981). Enhancing Employability, SCED paper 19, Standing conference on educational development, Oxford Polytechnic.

Hall, D. T. (1976). Careers in organizations. Glenview, IL: Scott, Foresman.

Herbert, I. P. \& Seal, W. B. (2014). A knowledge management perspective to shared service centers: A case study of a finance SSC. In T. V Bondarouk (Ed.), Shared services as a new organizational form. Advanced series in management, 13, Ch. 7 (pp. 131-151). WA: Emerald Group Publishing Limited.

Hillage J., \& Pollard E. (1998). Employability: Developing a framework for policy analysis (Research Report RR85). Brighton: Institute for Employment Studies/ DfEE.

Holmes, L. (2015). Becoming a graduate: The warranting of emergent identity. Education + Training, 57(2), 219-228.

Huffington, A. (2010). Third World America: How our politicians are abandoning the middle class and betraying the American dream. New York: Broadway paperbacks.

Jackson, D. (2013). Business graduate employability - where are we going wrong? Higher Education Research and Development, 32(5), 776-790.

James, S., Warhurst, C., Tholen, G., \& Commander, J. (2013). What we know and what we need to know about graduate skills. Work Employment and Society, $27(6), 952-963$.

Keep, E. (2010). Moving beyond skills as a social and economic panacea. Work Employment and Society, 24(3), 565-577. 
Kinash S., Crane L., Knight C., Dowling D., Mitchell K., (2014). Global graduate employability research, a report to the Businesss20 Human Capital Taskforce (draft), Learning and teaching papers, paper 100, Bond University.

Kochan T. A. (2012, March). Restoring U.S. competitiveness, a jobs compact for America's future. Harvard Business Review (reprint R1203C).

Krell, E. (2011). The global talent mismatch. HR Magazine, 56(6), 68-73.

Labour Bureau. (2014). Fourth annual employment and unemployment survey report. Chandigarh: Ministry of Labour and Employment.

Lallement, M. (2011). Europe and the economic crisis: Forms of labour market adjustment and varieties of capitalism. Work Employment and Society, 25(4), 741 627-641.

Leitch Review of Skills. (2006). Prosperity for all in the global economy: World class skills. Norwich: Her Majesty's Stationery Office (HMSO).

Lindsay, C., \& Dutton, M. (2010). Employability through health? Partnershipbased governance and the delivery of pathways to work condition management services. Policy Studies, 31(2), 245-264.

Lindsay, C., \& Mailand, M. (2009). Delivering employability in a vanguard 'active' welfare state: The case of greater Copenhagen in Denmark. Environment and Planning C: Government and Policy, 27(6), 1040-1054.

748

749

750

Lowden K., Hall S., Elliot D., Lewin J. (2011). Employers' perceptions of the employ- 751 ability skills of new graduates, SCRE Centre for Research in Education. EDGE Foundation, Glasgow.

Manyika, J., Lund, S., Auguste, B., Mendonca, L., Welsh, T., \& Ramaswamy, S. 754 (2011). An economy that works: Job creation and America's future. Washington: McKinsey Global Institute.

Manyika, J., Ramaswamy, S., Khanna, S., Sarrazin, H., Pinkus, G., Sethupathy, G., 757 et al. (2015). Digital America, a tale of the haves and have-mores. Washington: McKinsey Global Institute.

758

759

Maxwell R., \& Bennett S. (2015) When education met innovation met employabil- 760 ity: The birth of employability plus Conference Paper, 2015 AshokaU Exhange, University of Maryland, 26-28. http://nectar.northampton.ac.uk/7399/

McFall, S. L. (Ed.). (2012). Understanding society: Findings 2012. Colchester: Institute for Social and Economic Research, University of Essex.

763

McQuaid, R. W., \& Lindsay, C. (2005). The concept of employability. Urban 765 Studies, 42(2), 197-219.

Michaels E., Handfield-Jones H., Axelrod B. (1997). The war for talent, (McKinsey and Co). Boston: Harvard Business School Publishing.

Nauta, A., Van Vianen, A., Van der Heijden, B., Van Dam, K., \& Willemson, M. 769 (2009). Understanding the factors that promote employability orientation: 770 The impact of employability culture, career satisfaction, and role breadth self- 771 efficacy. Journal of Occupational and Organizational Psychology, 82(2), 772 233-257. 
805

NCIHE. (1997). Higher education in the learning society, report of the national inquiry into higher education (the 'dearing report). Norwich: HMSO.

Nwogu, G. A., \& Momoh, A. M. (2015). Graduate employability qualities and personality preference as determinants of job performance in Nigeria. European Scientific Journal, 11(25), 241-250.

OECD. (1995). Implementing the OECD jobs strategy, lessons from member countries' experience. Paris: Organisation for Economic Cooperation and Development.

OECD. (1996). The knowledge based economy. Paris: Organisation for Economic Cooperation and Development.

OECD. (1998). Human capital investment, an international comparison. Paris: Organisation for Economic Cooperation and Development.

Oliver, B. (2015). Redefining graduate employability and work-integrated learning: Proposals for effective higher education in disrupted economies. Journal of Teaching and Learning for Graduate Employability, 6(1), 56-65.

Orton, M. (2011). Flourishing lives: The capabilities approach as a framework for new thinking about employment, work and welfare in the 21 st century. Work Employment and Society, 25(2), 352-360.

Palley T. I. (2007, October 26-27). Financialization: What it is and why it matters. Working paper 525, The Levy Economics Institute. Conference paper at: 'Finance-led capitalism? Macroeconomic effects of changes in the financial sector', Berlin.

Pascale R. (1995, November/December). In search of the new employment contract. Human Resources, 21-26.

Pegg, A., Waldock, J., Hendy-Isaac, S., \& Lawton, R. (2012). Pedagogy for employability. York: Higher Education Academy.

Potgieter, I., \& Coetzee, M. (2013). Employability attributes and personality preferences of postgraduate business management students. SA Journal of Industrial Psychology/SA Tydskrif vir Bedryfsielkunde, 39(1), Art.1064, 10 pp Quintini, G. (2011). Over-qualified or under-skilled: A review of existing literature, OECD Social, Employment and Migration (Working Papers No. 121) OECD Publishing.

Redmond, P. (2010). The graduate jobs formula: How to land your dream career. Richmond: Trotman Publishing.

Rothwell, A., \& Arnold, J. (2007). Self-perceived employability, development and validation of a scale. Personnel Review, 36(1), 23-41.

Rothwell, A., \& Charleston, B. (2013). International volunteering: employability, leadership and more. Education + Training, 55(2), 159-173.

Rothwell, A., Herbert, I., \& Rothwell, F. (2008). Self-perceived employability: Construction and initial validation of a scale for university students. Journal of Vocational Behavior, 73, 1-12.

Rothwell, A., Jewell, S., \& Hardie, M. (2009). Self-perceived employability: Investigating the responses of post graduate students. Journal of Vocational Behavior, 75, 152-161. 
Rothwell, A., Herbert, I., \& Seal, W. (2011). Shared service centres and professional employability. Journal of Vocational Behavior, 79, 241-252.

Rufai, A. U., Bin, R. A., \& Bin Mat Rashid, A. (2015). Developing a sustainable practical model of graduate employability for higher education. International Journal of Education and Literacy Studies, 3(1), 42-54.

Scurry T., \& Blenkinsop J. (2011, December 7-9). Unknowing and unprepared? Undergraduate labour market outcomes and career management strategies. Conference paper, Society for research into higher education, Newport.

Sharma Y. (2014, July 1). What would you do with millions of extra graduates? BBC News. http://www.bbc.co.uk/news/business-28062071

Smith C., Ferns S., Russell C., \& Cretchley P. (2014). The impact of work integrated learning on student work readiness, Australian government, Office for Learning and Teaching. http://www.olt.gov.au/project-assessing-impactwork-integrated-learning-wil-student-work-readiness-2011

Tamkin, P., \& Hillage, J. (1999). Employability and employers: The missing piece of the jigsaw. Brighton: Institute for Employment Studies.

Thijssen, J. G. L., Van der Heijden, B. I. J. M., \& Rocco, T. S. (2008). Toward the employability-link model: Current employment transition to future employment perspectives. Human Resource Development Review, 7(2), 65-183.

Tibby M. (2012, May 16-17). Learning for life and work: Re-configuring employability for the 21 st century. Report on Teaching and Learning Summit, Manchester.

Torres R. (Ed.). (2012). World of work report 2012: Better jobs for a better economy. Geneva: International Labour Office.

UKCES. (2009). The employability challenge. London: UK Commission for Employability and Skills.

UN. (2001). Recommendations of the high level panel of the youth employment network. New York: United Nations.

Valanzuala, F. (2013). On employability in higher education and its relation to quality assurance: Between dis-identification and de-throning. Ephemera, 13(4), 861-873.

Van der Heijden, B. I. J. M. (2009). Age effects on the employability-career success relationship. Journal of Vocational behavior, 72(2), 156-164.

Van Emmerik, H. I. J., Schreurs, B., De Cuyper, N., Jawahar, I. M., \& Peeters, M. C. W. (2012). The route to employability, examining resources and the mediating role of motivation. Career Development International, 17(2), $104-119$. sures on professional life in the 1990s. Bristol: University of Bristol/Clerical Medical Investment Group.

Williams, J. (2012). Consuming higher education, why learning can't be bought. 858 London: Bloomsbury Academic. 
64 A. ROTHWELL AND F. ROTHWELL

860 Wilton, N. (2011). Do employability skills really matter in the UK graduate labour 861 862 market? The case of business and management graduates. Work Employment and Society, 25(1), 85-100.

863 Woodman, P., \& Hutchings, P. (2011). Tomorrow's leaders. London: Chartered 864 Management Institute.

865 World Economic Forum. (2016). The future of jobs, employment skills and work866 867 force strategy for the fourth industrial revolution. http://www.weforum.org/

868 Wright, J., Brinkley, I., \& Clayton, N. (2010). Employability and skills in the UK: 869 Redefining the debate. London: The Work Foundation. 


\section{Author Queries}

Chapter No.: $2 \quad 0002800301$

\begin{tabular}{|c|c|c|}
\hline Queries & Details Required & Author's Response \\
\hline AU1 & Please provide email address for corresponding author. & \\
\hline AU2 & Please check if identified head levels are okay. & \\
\hline AU3 & $\begin{array}{l}\text { "Thijssen et al. 2009" has been changed to "Thijssen et } \\
\text { al. 2008" as per the reference list. Please check if okay. }\end{array}$ & \\
\hline AU4 & $\begin{array}{l}\text { "Torres and Mahmoud } 2012 " \text { has been changed to } \\
\text { "Torres } 2012 " \text { as per the reference list. Please check if } \\
\text { okay. }\end{array}$ & \\
\hline AU5 & $\begin{array}{l}\text { "OECD (1997), Goldwyn-Simkins (2015), Orton } \\
\text { (2012), Chertkovskaya (2013), Robbins (1963), Ball } \\
\text { (2015), Sharma (2015), Waltz (2015), Van der Heijden et } \\
\text { al. (2009)" are cited in text but not given in the reference } \\
\text { list. Please provide details in the list or delete the citation } \\
\text { from the text. }\end{array}$ & \\
\hline AU6 & Please specify "a" or "b" for CIPD (2015). & \\
\hline AU7 & $\begin{array}{l}\text { "Kinash et al. (2015)" has been changed to "Kinash et } \\
\text { al. (2014)" as per the reference list. Please check if okay. }\end{array}$ & \\
\hline AU8 & $\begin{array}{l}\text { "Waltz (2015)" has been changed to "Waltz (2011)" as } \\
\text { per the reference list. Please check if okay. }\end{array}$ & \\
\hline AU9 & $\begin{array}{l}\text { References "Bernstein (2000), Brown and Hesketh } \\
\text { (2004), CEDEFOP (2009), Committee on Higher } \\
\text { Education (1963), Crompton (2010), Davis et al. (2015), } \\
\text { Grist et al. (2011), Krell (2011), Lallement (2011), } \\
\text { Lindsay and Dutton (2010), Lindsay and Mailand } \\
\text { (2009), McFall (2012), Quintini (2011), Van der Heijden } \\
\text { (2009)" are not cited in the text. Please cite in text. }\end{array}$ & \\
\hline AU10 & $\begin{array}{l}\text { Please provide publisher location for Kinash et al. } \\
\text { (2014). }\end{array}$ & \\
\hline
\end{tabular}

